\title{
HIGH LEVELS OF CATALASE IN SOD MUTANTS OF SACCHAROMYCES CEREVISIAE IN HIGH AERATION CONDITIONS
}

\author{
Vanessa Martins $^{1,2}$; Vanusa Manfredini' ${ }^{2}$ Mara Silveira Benfato ${ }^{1,2 *}$ \\ ${ }^{1}$ Departamento de Biofísica, Instituto de Biociências, Universidade Federal do Rio Grande do Sul, Porto Alegre, Brasil. \\ ${ }^{2}$ Programa de Pós-Graduação em Biologia Celular e Molecular, Universidade Federal do Rio Grande do Sul, Porto Alegre, Brasil
}

Submitted: February 18, 2005; Returned to authors for corrections: May 27, 2005; Approved: November 03, 2005

\begin{abstract}
Saccharomyces cerevisiae mutants deficient in superoxide dismutase genes $(\operatorname{sod} 1 \Delta, \operatorname{sod} 2 \Delta$ and $\operatorname{sod} 1 \Delta \operatorname{sod} 2 \Delta$ mutants) in a stationary phase of growth under high aeration conditions were subjected to $\mathrm{H}_{2} \mathrm{O}_{2}$ stress. All the mutants were sensitive after $\mathrm{H}_{2} \mathrm{O}_{2}$ treatment. Glutathione peroxidase levels were significantly lower in sodl $\Delta$ and $\operatorname{sod} 2 \Delta$ single mutants than in the wild-type without treatment. After exposure to $\mathrm{H}_{2} \mathrm{O}_{2}$ concentrations, glutathione peroxidase levels were increased in $\operatorname{sod} 1 \Delta \operatorname{sod} 2 \Delta$ double mutants and the $\operatorname{sod} 2 \Delta$ single mutant, while sod $1 \Delta$ maintained lower gluthatione peroxidase activities. The sod $2 \Delta$ mutant demonstrated a similar catalase activity to that of the wild-type without treatment, whilst decreased catalase activity was observed in conditions of low aeration. Untreated $\operatorname{sod} 1 \Delta \operatorname{sod} 2 \Delta$ double mutant cells presented a lower catalase activity. Catalase levels were higher under high aeration conditions than under microaerophilic conditions, including in sodl $\Delta \operatorname{sod} 2 \Delta$ cells that contain less $\mathrm{H}_{2} \mathrm{O}_{2}$, since SOD catalyzes the cleavage of superoxide producing $\mathrm{H}_{2} \mathrm{O}_{2}$ and oxygen. We suggest that catalase is not essential for sod mutants under normal conditions, but plays an important role in the acquisition of tolerance to oxidative stress induced by high aeration.
\end{abstract}

Key words: catalase, superoxide dismutase, high aeration, hydrogen peroxide, S. cerevisiae

\section{INTRODUCTION}

The reduction of oxygen to water supplies the necessary energy for the several functions of our organism. The incomplete reduction of oxygen to water during respiration, however, leads to the formation of redox-active oxygen species (ROS) such as the superoxide anion radical $\left(\mathrm{O}_{2}{ }^{\circ}\right)$, the hydroxyl radical $\left({ }^{\circ} \mathrm{OH}\right)$ and hydrogen peroxide $\left(\mathrm{H}_{2} \mathrm{O}_{2}\right)$ (2). Studies suggest that mitochondrial respiration is a major source of ROS in vivo, as has been shown in vitro, and that these species are produced even under low aeration (7). These ROS have been shown to cause critical damage to DNA, protein and cellular membranes (6).

To defend the organism against ROS, the cell possesses antioxidant enzymes such as glutathione peroxidase (GPx), catalase (CAT) and superoxide dismutase (SOD). Catalase, known to be one of the most efficient enzymes, reacts with
$\mathrm{H}_{2} \mathrm{O}_{2}$ to form water and molecular oxygen. Glutathione peroxidase removes hydroperoxides $\left(\mathrm{ROOH}\right.$ and $\left.\mathrm{H}_{2} \mathrm{O}_{2}\right)$ by coupling its reduction to $\mathrm{H}_{2} \mathrm{O}$ with oxidation of reduced glutathione (GSH). Superoxide dismutase removes superoxide by converting it to peroxide that can, in turn, be destroyed by CAT or GPx reactions (10).

Saccharomyces cerevisiae, like most other eukaryotes, contains CuZnSOD (the product of the SOD1 gene) in the cytosol, nucleus, and lysosomes and MnSOD (the product of the SOD2 gene) in the mitochondrial matrix.

MnSOD is believed to be the major means of protection against mitochondrial superoxide (4). The sources of ROS relevant to CuZnSOD are less clear because of the location of this enzyme within the cytosol. Neither MnSOD nor CuZnSOD is strictly essential; however, the loss of CuZnSOD has dramatic phenotypic consequences in yeast. Yeast strains lacking $\mathrm{CuZnSOD}(\operatorname{sod} 1 \Delta)$ show reduced growth rates in glycerol and

*Corresponding Author. Mailing address: Departamento de Biofísica, Instituto de Biociências, Universidade Federal do Rio Grande do Sul, Av. Bento Gonçalves 9500, Prédio 43422. 91501-970, Porto Alegre, RS, Brasil. Tel: (+5551) 3316-7603; Fax: (+5551) 3316-7003; E-mail: mara.benfato@.ufrgs.br 
ethanol, auxotrophy for lysine and methionine or cysteine, a higher rate of spontaneous mutation and more rapid loss of viability in the stationary phase $(3,7,9)$. sod $2 \Delta$ mutants are oxygen-sensitive and, when required to utilize oxygen, grow poorly. The most severely affected are the $\operatorname{sod} 1 \Delta \operatorname{sod} 2 \Delta$ double mutants exhibiting essentially all the characteristics of the single mutant phenotypes.

Growth of a yeast culture consists of three stages. First, there is a period of rapid logarithmic growth, where metabolism is primarily glycolytic. As the glucose is consumed, the culture switches to respiratory growth (known as the diauxic shift) and then to a stationary phase during which energy is generated primarily in the mitochondria. In the stationary phase, yeast stop dividing and exhibit lower metabolic rates, increased antioxidant defenses and are able to survive for weeks to months without additional nutrients (8).

Previous studies performed in our laboratory evaluated the activities of the antioxidant enzymes (CAT and GPx) and the sensibility of the sod mutants to $\mathrm{H}_{2} \mathrm{O}_{2}$ in microaerophilic conditions (9). The highest sensitivity to $\mathrm{H}_{2} \mathrm{O}_{2}$ was observed in the $\operatorname{sod} 2 \Delta$ mutant, while the $\operatorname{sod} 1 \Delta \operatorname{sod} 2 \Delta$ double mutant was not sensitive. sod mutants had lower catalase activity (44\%) than wild-type cells, independent of $\mathrm{H}_{2} \mathrm{O}_{2}$ stress. Untreated cells of $\operatorname{sod} 1 \Delta \operatorname{sod} 2 \Delta$ double mutant showed increased glutathione peroxidase activity (126\%), while sod $1 \Delta$ had lower activity ( $77 \%$ ) than the wild-type. These results suggest that the resistance to $\mathrm{H}_{2} \mathrm{O}_{2}$ by $\operatorname{sod} 1 \Delta \operatorname{sod} 2 \Delta$ cells depends on the induction of glutathione peroxidase and is independent of catalase in stationary phase and microaerophilic conditions (9). Because the level of oxygen modifies the concentration of ROS in the cell, the present investigation intends to evaluate the alterations occurring in the mechanisms of antioxidant defense of the yeast in conditions of high aeration, making a comparison with the results obtained in microaerophilic conditions.

\section{MATERIALS AND METHODS}

\section{Strains of Saccharomyces cerevisiae}

The wild-type $S$. cerevisiae strain, EG103, and the isogenic mutant strains, $\operatorname{sod} 1 \Delta, \operatorname{sod} 2 \Delta$ and $\operatorname{sod} 1 \Delta \operatorname{sod} 2 \Delta$ were kindly provided by Dr. E. Gralla (University of California, Los Angeles, CA, USA). Disruption of the SOD1 and SOD2 genes was performed as described previously $(3,6)$. The relevant genotypes of the strains are listed in Table 1.

\section{Media and growth conditions}

Yeast strains were grown at $30^{\circ} \mathrm{C}$ in YPD liquid medium containing $2 \%$ glucose, $1 \%$ yeast extract and $2 \%$ bacto-peptone. The flask volume/medium ratio was 5:1 (high aeration conditions) and flasks were shaken at $200 \mathrm{rpm}$. For solid medium, $2 \%$ agar was added (12). The cell lines lacking CuZnSOD were continually monitored for suppressor activity $(3,7)$.
Table 1. Yeast strains used in this study.

\begin{tabular}{|c|c|c|}
\hline Yeast Strain & Genotype & Ref. \\
\hline EG103 & $\begin{array}{l}\text { (DBY746) MATa leu2-3, } 112 \\
\text { his3 } 41 \text { trp1-289 ura3-52 GAL+ }\end{array}$ & 3 \\
\hline EG118 & EG103 with $\operatorname{sod} 1 \triangle:: U R A 3$ & 3 \\
\hline EG110 & EG103 with $\operatorname{sod} 2 \triangle:: T R P 1$ & 6 \\
\hline EG133 & EG103 with sod $1 \triangle:: U R A 3 \operatorname{sod} 2 \Delta:: T R P 1$ & 6 \\
\hline
\end{tabular}

\section{Hydrogen peroxide treatment}

Yeast cells were grown to the stationary phase $\left(1-2 \times 10^{8}\right.$ cell $/ \mathrm{mL}$ ) in YPD medium at $30^{\circ} \mathrm{C}$. Cells were harvested and washed in sterile saline $(0.9 \% \mathrm{NaCl})$ and the cell pellets were resuspended in saline and treated with increasing concentrations of $\mathrm{H}_{2} \mathrm{O}_{2}(0.5-5.0 \mathrm{mM})$ at $30^{\circ} \mathrm{C}$ for $1 \mathrm{~h}$.

For dose-response curves, aliquots of cells were diluted in saline and plated in triplicate onto YPD to obtain viable counts after 3-5 days of growth at $30^{\circ} \mathrm{C}$.

\section{Enzyme activities}

Crude extracts were prepared by glass beads lysis as follows: cells were suspended in lysis buffer $(50 \mathrm{mM}$ Tris, $150 \mathrm{mM} \mathrm{NaCl}$, $50 \mathrm{mM}$ EDTA, and $0.2 \mathrm{mM}$ phenylmethylsulfonyl fluoride $\mathrm{pH}$ 7.2) with an equal volume of acid washed $425-600 \mu \mathrm{m}$ glass beads, vortexed for $10-15$ cycles ( 30 s each), followed by 30 s of cooling. The mixture was then microcentrifuged for $2 \mathrm{~min}$ to remove the cellular debris and glass beads (7).

CAT activity was determined spectrophotometrically by monitoring the disappearance of $\mathrm{H}_{2} \mathrm{O}_{2}$ at $240 \mathrm{~nm}$ (13). GPx activity was determined by monitoring the NADPH consumption rate at $340 \mathrm{~nm}$ (11). Protein concentration was determined by the Bradford assay (1).

\section{Statistical analysis}

Results are reported as means \pm SD and were analyzed by the Student's $t$ test. Values of $\mathrm{P}<0.05$ were considered to be statistically significant.

\section{RESULTS AND DISCUSSION}

Wild-type and sod null mutant cultures in the stationary phase of growth under high aeration conditions were treated with increasing levels of $\mathrm{H}_{2} \mathrm{O}_{2}$ for $1 \mathrm{~h}$ at $30^{\circ} \mathrm{C}$ under non-growth conditions (Fig. 1). All the mutants were sensitive to the treatment with $\mathrm{H}_{2} \mathrm{O}_{2}$. The $\operatorname{sod} 2 \Delta$ single mutant and the $\operatorname{sod} 1 \Delta \operatorname{sod} 2 \Delta$ double mutant were the most sensitive in relation to the isogenic parent strain. Under microaerophilic conditions, the sensivity of the $\operatorname{sod} 1 \Delta \operatorname{sod} 2 \Delta$ double mutant was indistinguishable from that of the wild type (9). 
Evaluating the CAT activity (Fig. 2), it was demonstrated that without treatment the sod $2 \Delta$ mutant showed similar CAT activity levels to those of the wild-type. In contrast, under low aeration conditions decreased CAT activity was observed in simple and double mutants (Table 2). The $\operatorname{sod} 1 \Delta \operatorname{sod} 2 \Delta$ double mutant, without treatment, presented the lowest levels of CAT, maintaining these low levels after the treatment with $\mathrm{H}_{2} \mathrm{O}_{2}$ in high aeration (Fig. 2). Under microaerophilic conditions (9), the CAT activity profile was similar, with the $\operatorname{sod} 1 \Delta \operatorname{sod} 2 \Delta$ double mutant presenting the lowest enzymatic induction (5 $\mathrm{mM} \mathrm{H}_{2} \mathrm{O}_{2}, 11.7 \%$ ). Conversely, the $\operatorname{sod} 2 \Delta$ single mutant, after $\mathrm{H}_{2} \mathrm{O}_{2}$ treatment in high aeration, demonstrated the CAT highest activity compared to the wild-type (Fig. 2). A different result was observed in the sodl $\triangle \Delta$ mutant, which initially presented a lower enzymatic activity to that of $S O D+$, but after treatment demonstrated similar levels of induction to those of the wildtype (Fig. 2). Interestingly, the CAT levels under high aeration were much higher than under microaerophilic conditions (Table 2), suggesting that this modification in the aeration level, during the growth of the yeast, induces an increase in the $\mathrm{H}_{2} \mathrm{O}_{2}$ concentration. Surprisingly, the highest CAT level was also observed in the $\operatorname{sod} 1 \Delta \operatorname{sod} 2 \Delta$ double mutant $(188 \%$ in the control), although this level was significantly lower than that of the wild-type (278\% in the control). sodl $\Delta \operatorname{sod} 2 \Delta$ double mutant cells contain less $\mathrm{H}_{2} \mathrm{O}_{2}(5)$ since SOD catalyzes the cleavage of superoxide, producing $\mathrm{H}_{2} \mathrm{O}_{2}$ and oxygen. With regard to GPx activity, the $\operatorname{sod} 1 \Delta \operatorname{sod} 2 \Delta$ double mutant, without treatment, presented similar enzymatic levels to those of the wild-type (Fig. 3, Table 1). After the treatment, this mutant presented the highest GPx activity in comparison with the same untreated cells (1.0 and $5.0 \mathrm{mM} \mathrm{H}_{2} \mathrm{O}_{2}$ ). After $\mathrm{H}_{2} \mathrm{O}_{2}$ treatment, GPx levels were significantly increased when exposed to $0.5-1.0 \mathrm{mM} \mathrm{H} \mathrm{H}_{2}$ in the $\operatorname{sod} 2 \Delta$, while $\operatorname{sod} 1 \Delta$ maintained lower GPx activities. However, the high levels of enzymatic activity are not capable of providing these mutants

Table 2. U/mg protein values of CAT and GPx in microaerophilic and high aeration conditions (mean $\pm \mathrm{SD}$ ).

\begin{tabular}{cllll}
\hline \multirow{2}{*}{ Mutant } & \multicolumn{2}{c}{ Microaerophilic aeration* } & \multicolumn{2}{c}{ High aeration } \\
\cline { 2 - 5 } & \multicolumn{1}{c}{ CAT } & \multicolumn{1}{c}{ GPx } & CAT & GPx \\
\hline SOD $^{+}$ & $32.2 \pm 4.6$ & $26.8 \pm 1.6$ & $89.6 \pm 4.3^{\mathrm{a}}$ & $52.6 \pm 1.4^{\mathrm{a}}$ \\
$\operatorname{sod} 1 \Delta$ & $15.0 \pm 3.2^{\mathrm{b}}$ & $21.2 \pm 0.4^{\mathrm{b}}$ & $59.2 \pm 0.3^{\mathrm{ab}}$ & $48.3 \pm 3.0^{\mathrm{a}}$ \\
$\operatorname{sod} 2 \Delta$ & $22.2 \pm 2.6^{\mathrm{bc}}$ & $30.3 \pm 1.4^{\mathrm{bc}}$ & $86.6 \pm 2.4^{\text {ac }}$ & $49.8 \pm 1.7^{\mathrm{a}}$ \\
sod1 $1 \operatorname{sod} 2 \Delta$ & $14.3 \pm 2.6^{\mathrm{bd}}$ & $34.2 \pm 0.5^{\mathrm{bcd}}$ & $26.9 \pm 1.9^{\text {abcd }}$ & $54.3 \pm 6.3^{\text {a }}$ \\
\hline
\end{tabular}

* Manfredini et al., 2004 (9); a different from the same strain in microaerophilic aeration, $\mathrm{P}<0.05$; ${ }^{\mathrm{b}}$ different from $\mathrm{SOD}^{+}$in the same aeration condition, $\mathrm{P}<0.05$; ${ }^{\mathrm{c}}$ different from sod $1 \Delta$ in the same aeration condition, $\mathrm{P}<0.05 ;{ }^{\mathrm{c}}$ different from $\operatorname{sod} 2 \Delta$ in the same aeration condition, $\mathrm{P}<0.05 ;{ }^{\mathrm{d}}$ different from $\operatorname{sod} 1 \Delta \operatorname{sod} 2 \Delta$ in the same aeration condition, $\mathrm{P}<0.05$.

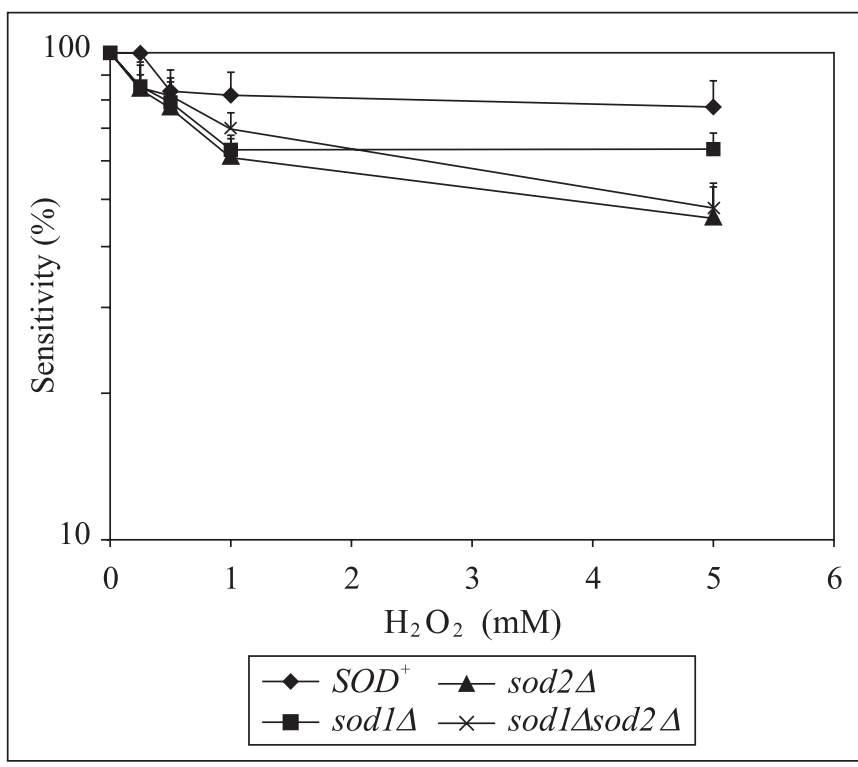

Figure 1. Sensitivity of sod null mutants to $\mathrm{H}_{2} \mathrm{O}_{2}$. The strains used were: $\checkmark S^{+} D^{+}, \boldsymbol{\square} \operatorname{sod} 1 \Delta, \boldsymbol{\Delta} \operatorname{sod} 2 \Delta$ and $\mathbf{x} \operatorname{sod} 1 \Delta \operatorname{sod} 2 \Delta$. Data represent the mean $\pm \mathrm{SD}$ of three independent experiments.

with resistance against $\mathrm{H}_{2} \mathrm{O}_{2}$, since they were affected in the sensibility test.

Evaluating the GPx activity without treatment, it was demonstrated that the enzymatic levels are much greater under high aeration conditions, as also seen with the CAT enzymatic levels (Table 2). The CAT levels were, on average, $200 \%$ greater under high aeration, whilst the activity of GPx was increased by $80 \%$ compared to the microaerophilic conditions values. The oxidative stress in stationary cultures of yeast may be the consequence of the improved availability of oxygen to the cells, due to a decreased metabolism. Metabolically active cells intensively consume oxygen under conditions of limited aeration, which may lead to low oxygen concentrations within the cells. In stationary cultures, the metabolism is considerably attenuated and, as such, the oxygen concentration within cells may be higher. One-electron reactions of autoxidation-prone cellular components may produce superoxide and, in turn, other reactive oxygen species. The increase in the levels of antioxidant enzymes in yeast entering the stationary phase may, therefore, constitute an adaptative response to the enhanced oxidative damage. In this study, the increase in CAT and GPx activities may also represent a stress response generated by high aeration. These results suggest that catalase is not essential for yeast cells under normal conditions of aeration in these cells, while GPx activities are more important under low aeration conditions. 


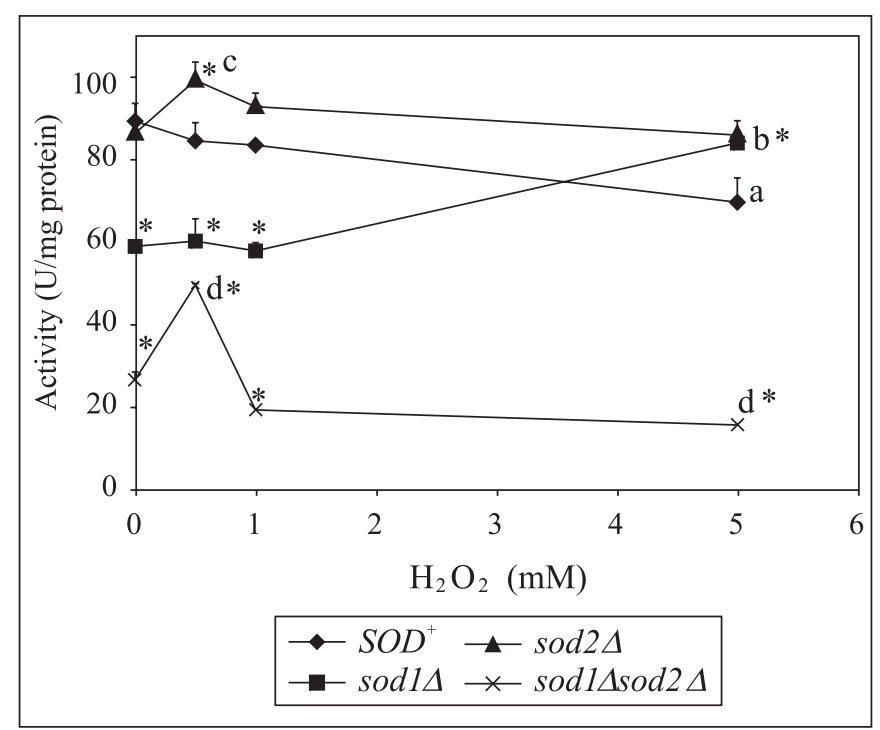

Figure 2. Activity of CAT in wild-type cells ans sod mutant cells exposed to $\mathrm{H}_{2} \mathrm{O}_{2}$. Cells in the stationary phase were treated with the indicated concentrations fo $\mathrm{H}_{2} \mathrm{O}_{2}$ in sterile saline $(0.9 \%$ $\mathrm{NaCl}$ ). For the catalase activity, the rate of decrease in $\mathrm{H}_{2} \mathrm{O}_{2}$ absorbance at $240 \mathrm{~nm}$ was measured. The strains used were: $\checkmark S_{O D}, \mathbf{\square} \operatorname{sod} 1 \Delta, \mathbf{\Delta} \operatorname{sod} 2 \Delta$ and $\mathbf{x} \operatorname{sod} 1 \Delta \operatorname{sod} 2 \Delta$. Data represent the mean $\pm \mathrm{SD}$ of three independent experiments. ${ }^{\text {a }}$ different from $S O D^{+}$untreated cells, $\mathrm{p}<0.05$; ${ }^{\mathrm{b}}$ different from sodl $\Delta$ untreated cells, $\mathrm{p}<0.05 ;{ }^{\mathrm{c}}$ different from sod $2 \Delta$ untreated cells, $\mathrm{p}<0.05 ;{ }^{\mathrm{d}}$ different from sod $1 \Delta \operatorname{sod} 2 \Delta$ untreated cells, $\mathrm{p}<0.05$; * different from $\mathrm{SOD}^{+}$in the same point.

\section{ACKNOWLEDGEMENTS}

We would like to Dr. C. R. Carlini and J.A.P. Henriques for generously providing equipment. This work was supported by grants from PROPESQ-UFRGS.

\section{RESUMO}

\section{Altos níveis de catalase em mutantes sod de Saccharomyces cerevisiae em condições de alta aeração}

Saccharomyces cerevisiae deficientes nos genes da superóxido dismutase (mutantes $\operatorname{sod} 1 \Delta, \operatorname{sod} 2 \Delta$ e $\operatorname{sod} 1 \Delta \operatorname{sod} 2 \Delta$ ) cultivados em fase estacionária sob condições de alta aeração foram submetidos ao estresse com peróxido de hidrogênio $\left(\mathrm{H}_{2} \mathrm{O}_{2}\right)$. Todos os mutantes mostraram-se sensíveis após o tratamento com o $\mathrm{H}_{2} \mathrm{O}_{2}$. A enzima glutationa peroxidase (GPX) apresentou níveis significativamente mais baixos nos simples mutantes $\operatorname{sod} 1 \Delta$ e $\operatorname{sod} 2 \Delta$ que na cepa selvagem sem tratamento.

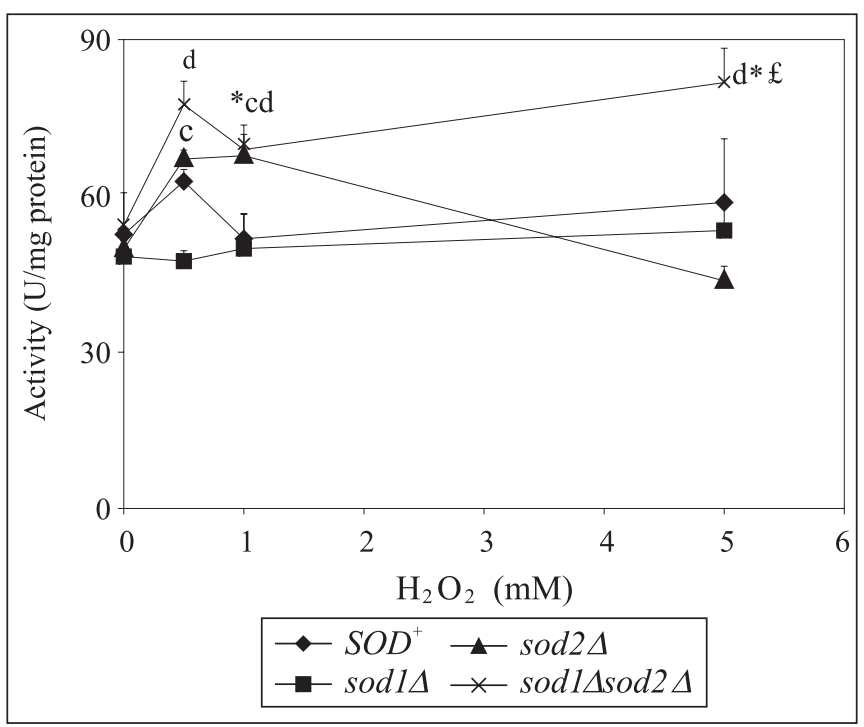

Figure 3. Activity of glutathione in wild-type cells ans sod mutant cells exposed to $\mathrm{H}_{2} \mathrm{O}_{2}$. Cells were treated as described in the legend to Fig. 3. For the determination of glutathione peroxidase activity, the rate of NADPH oxidation was followed at $340 \mathrm{~nm}$. The strains used were: $\mathrm{SOD}^{+}, \mathbf{a} \operatorname{sod} 1 \Delta, \mathbf{\Delta} \operatorname{sod} 2 \Delta$ and $\mathbf{x} \operatorname{sod} 1 \Delta \operatorname{sod} 2 \Delta$. Data represent the mean $\pm \mathrm{SD}$ of two independent experiments. ${ }^{a}$ different from $S O D^{+}$untreated cells, $\mathrm{p}<0.05 ;{ }^{\mathrm{b}}$ different from sod $1 \Delta$ untreated cells, $\mathrm{p}<0.05$; ${ }^{\mathrm{c}}$ different from $\operatorname{sod} 2 \Delta$ untreated cells, $\mathrm{p}<0.05 ;{ }^{\mathrm{d}}$ different from $\operatorname{sod} 1 \Delta \operatorname{sod} 2 \Delta$ untreated cells, $\mathrm{p}<0.05 ; *$ different from $S O D^{+}$ in the same point, $\mathrm{p}<0.05 ;{ }^{£}$ different from sod $1 \Delta$ treated cells with $5 \mathrm{mM} \mathrm{H}_{2} \mathrm{O}_{2}, \mathrm{p}<0.05$.

Após, a exposição a diferentes concentrações de $\mathrm{H}_{2} \mathrm{O}_{2}$, os níveis da glutationa peroxidase aumentaram no duplo mutante $\operatorname{sod} 1 \Delta \operatorname{sod} 2 \Delta$ e no simples mutante $\operatorname{sod} 2 \Delta$, enquanto o mutante sodl $\Delta$ manteve baixa atividade da glutationa peroxidase. $\mathrm{O}$ mutante $\operatorname{sod} 2 \Delta$ demonstrou atividade da catalase similar a da cepa selvagem sem tratamento, enquanto foi observado que a atividade da catalase decresceu em condições de baixa aeração. O duplo mutante $\operatorname{sod} 1 \Delta \operatorname{sod} 2 \Delta$ apresentou baixa atividade da catalase mesmo sem tratamento. Os níveis da catalase foram maiores em condições de alta aeração do que em condições microaerófilas, inclusive o duplo mutante $\operatorname{sod} 1 \Delta \operatorname{sod} 2 \Delta$ contém menos $\mathrm{H}_{2} \mathrm{O}_{2}$, visto que, a SOD catalisa a clivagem do superóxido produzindo $\mathrm{H}_{2} \mathrm{O}_{2}$ e oxigênio. Nós sugerimos neste trabalho que a catalase não é essencial para os mutantes sod sob condições normais, mas ela participa de uma importante via na aquisição da tolerância ao estresse oxidativo induzido por condições de alta aeração.

Palavras-chave: catalase, superóxido dismutase, alta aeração, peróxido de hidrogênio, $S$. cerevisiae 


\section{REFERENCES}

1. Bradford, M. A Rapid and sensitive Method for the Quantitation of Microgram Quantities of Protein Utilizing the Principle of Protein Dye binding. Anal. Biochem., 72, 248-254, 1976.

2. Godon, C.; Lagniel, G.; Lee, J.; Buhler, J.M.; Kieffer, S.; Perrot, M.; Boucherie, H.; Toledano, M.B.; Labarre, J. The $\mathrm{H}_{2} \mathrm{O}_{2}$ stimulon in Saccharomyces cerevisiae. J. Biol. Chem., 273, 22480-22489, 1998.

3. Gralla, E.B.; Valentine, J.S. Null Mutants of Saccharomyces cerevisiae $\mathrm{Cu}, \mathrm{Zn}$ Superoxide Dismutase: Characterization and Spontaneous Mutation Rates. J. Bacteriol., 173, 5918-5920, 1991.

4. Gralla, E.B.; Kosman, D.J. Molecular-genetics of superoxide dismutases in yeasts and related Fungi. Adv. Genet., 30, 251-319, 1992

5. Jakubowski, W.; Bilinski, T.; Bartosz, G. Oxidative Stress During of stationary Cultures of the Yeast Saccharomyces cerevisiae. Free Radic. Biol. Med., 28, 659-664, 2000.

6. Liu, X.F.; Elashvili, I.; Gralla, E.B.; Valentine, J.S.; Lapinskas, P.; Culotta, V.C. Yeast lacking superoxide-dismutase - isolation of genetic supressors. J. Biol. Chem., 267, 18298-18302, 1992.
7. Longo, V.D.; Gralla, E.B.; Valentine, J.S. Superoxide Dismutase Activity Is Essential for Stationary Phase Survival in Saccharomyces cerevisiae. J. Biol. Chem., 271, 12275-12280, 1996.

8. Longo, V.D.; Liou, L.L.; Valentine, J.S.; Gralla, E.B. Mitochondrial Superoxide Decreases Yeast Survival in Stationary Phase. Archiv. Biochem. Biophys., 365, 131-142, 1999.

9. Manfredini, V.; Roehrs, R.; Peralba, M.C.; Henriques, J.A.P.; Saffi, J.; Ramos, A.L.P.; Benfato, M.S. Glutathione Peroxidase Induction Protects sod1 $\Delta \operatorname{sod} 2 \Delta$ ? Double Mutants Against Oxidative Damage in S. cerevisiae. Braz. J. Med. Biol. Res., 37, 161-165, 2004.

10. Matés, J.M. Effects of antioxidant enzymes in the molecular control of reactive oxigen species toxicology. Toxicol., 153, 83-104, 2000.

11. Pinto, R.E.; Bartley, W. Effect of age and sex on Glutathione reductase and Glutathione peroxidase activities and on aerobic Glutathione oxidation in rat liver homogenates. Biochem. J., 112, 109-115, 1969.

12. Shermann, F.; Fink, G. R.; Hicks, J.B. Methods in Yeast Genetics. Cold Spring Harbor, New York, 1986, 402p.

13. Taniguchi, N.; Gutteridge, J. M. C. Experimental Protocols for Reactive Oxygen and Nitrogen Species. 1st Ed, Oxford University Press, New York, 2000, 337p. 